\title{
Aluminum exclusion and aluminum tolerance in woody plants
}

\section{Ivano Brunner* and Christoph Sperisen}

Forest Soils and Biogeochemistry, Swiss Federal Institute for Forest, Snow and Landscape Research, Birmensdorf, Switzerland

\section{Edited by:}

Boris Rewald, University of Natural Resources and Life Sciences, Austria

\section{Reviewed by:}

Peter Ryan, Commonwealth Scientific and Industrial Research Organisation, Australia

Jonathan Cumming, West Virginia

University, USA

\section{${ }^{*}$ Correspondence:}

Ivano Brunner, Forest Soils and Biogeochemistry, Swiss Federal Institute for Forest, Snow and Landscape Research, Zürcherstrasse 111, CH-8903 Birmensdorf, Switzerland

e-mail: ivano.brunner@wsl.ch
The aluminum (Al) cation $\mathrm{Al}^{3+}$ is highly rhizotoxic and is a major stress factor to plants on acid soils, which cover large areas of tropical and boreal regions. Many woody plant species are native to acid soils and are well adapted to high $\mathrm{Al}^{3+}$ conditions. In tropical regions, both woody Al accumulator and non-Al accumulator plants occur, whereas in boreal regions woody plants are non-Al accumulators. The mechanisms of these adaptations can be divided into those that facilitate the exclusion of $\mathrm{Al}^{3+}$ from root cells (exclusion mechanisms) and those that enable plants to tolerate $\mathrm{Al}^{3+}$ once it has entered the root and shoot symplast (internal tolerance mechanisms). The biochemical and molecular basis of these mechanisms have been intensively studied in several crop plants and the model plant Arabidopsis. In this review, we examine the current understanding of $\mathrm{Al}^{3+}$ exclusion and tolerance mechanisms from woody plants. In addition, we discuss the ecology of woody non-Al accumulator and $\mathrm{Al}$ accumulator plants, and present examples of $\mathrm{Al}^{3+}$ adaptations in woody plant populations. This paper complements previous reviews focusing on crop plants and provides insights into evolutionary processes operating in plant communities that are widespread on acid soils.

Keywords: acid soils, adaptation, aluminum, organic acids, tolerance, resistance, toxicity

\section{INTRODUCTION}

Aluminum $(\mathrm{Al})$ is a prevalent constituent of most soils and is one of the major stresses to plants in acid soils. Most of the $\mathrm{Al}$ in soils is incorporated into aluminosilicates and other precipitated forms, which are harmless to plants. Under acid soil conditions, these minerals solubilize to a limited extent, and the toxic ion $\mathrm{Al}^{3+}$ is released into the soil solution (Kinraide, 1997). This form of $\mathrm{Al}$ is capable of inhibiting root growth and damaging cells at the root apex, which is the most sensitive part of the root to $\mathrm{Al}^{3+}$ (Ryan et al., 1993; Kochian, 1995). However, the mechanism underlying $\mathrm{Al}^{3+}$ toxicity is not clearly understood. Because $\mathrm{Al}^{3+}$ can interact with a number of extracellular and intracellular structures, many different mechanisms of $\mathrm{Al}^{3+}$ toxicity have been proposed. These mechanisms include modification of the cell wall, disruption of the plasma membrane and transport processes, interruption of signaling pathways, and $\mathrm{Al}^{3+}$ binding to the DNA (Kochian et al., 2005).

$\mathrm{Al}^{3+}$ toxicity is an important research topic, because many crop plants are susceptible in acid soils, and their growth and yield are limited by high $\mathrm{Al}^{3+}$ conditions. Less attention is paid to native plant communities, which tolerate acid soil conditions over large areas in different biomes. Acid soils occupy about $30 \%$ of the icefree land area in the world and primarily occur in the humid tropics and the boreal region. Large parts of these soils (about 67\%) are covered by forests and woodland (von Uexküll and Mutert, 1995; Figure 1). The biodiversity and high biomass production of both tropical and boreal forests suggest that their plants are not affected by $\mathrm{Al}^{3+}$ toxicity.

$\mathrm{Al}^{3+}$ toxicity may occur in forests that are exposed to acid deposition derived from air pollutants (Cronan and Schofield, 1979;
Ulrich etal., 1980; Larssen et al., 2006). On sensitive sites, acid deposition accelerates soil acidification and leads to increased $\mathrm{Al}^{3+}$ concentrations in the soil solution (Blaser et al., 1999; Fowler et al., 1999). Recently, it was found that soils, affected by acid deposition, showed signs of recovery due to the reduction in sulfate deposition (Stoddard et al., 1999; Evans et al., 2001). However, inputs of nitric acid and ammonia continue to alter the chemistry of forest soils and are likely to promote acidification (Graf Pannatier et al., 2011; Zang et al., 2011). Acid soils characteristically contain high amounts of $\mathrm{Al}^{3+}$ and low amounts of the base cations (BC) $\mathrm{Ca}^{2+}$, $\mathrm{Mg}^{2+}$, and $\mathrm{K}^{+}$, which are important plant nutrients. Since $\mathrm{Al}^{3+}$ and $\mathrm{BC}$ interact at the plasma membrane surface, it is not the soil $\mathrm{Al}^{3+}$ concentration alone that determines the plant responses to $\mathrm{Al}^{3+}$ exposure (Sverdrup and Warfvinge, 1993; Cronan and Grigal, 1995; Kinraide, 2003). A ratio of $\mathrm{Ca}^{2+} / \mathrm{Al}^{3+}$ or BC/Al ${ }^{3+}$ in the soil solution lower than 1 is widely used as an ecological indicator for potentially adverse effects of $\mathrm{Al}^{3+}$ stress and nutrient imbalance on tree growth. Alternative indicators are based on the $\mathrm{Al}$ and $\mathrm{Ca}$ concentrations in fine roots and provide information on the availability of toxic $\mathrm{Al}^{3+}$ in the soils (e.g., Brunner et al., 2004; Richter et al., 2007; Vanguelova et al., 2007).

\section{$\mathrm{Al}^{3+}$ EXCLUSION AND $\mathrm{Al}^{3+}$ TOLERANCE MECHANISMS}

The mechanisms conferring resistance to $\mathrm{Al}^{3+}$ have been the focus of intensive research in crop plants and in the model plant Arabidopsis. Many different mechanisms have been suggested, but for most of them, the supporting genetic and physiological evidence is not provided. Therefore, these mechanisms have to remain speculation or hypotheses until supporting data is provided. One exception is the $\mathrm{Al}^{3+}$-induced efflux of organic acids 

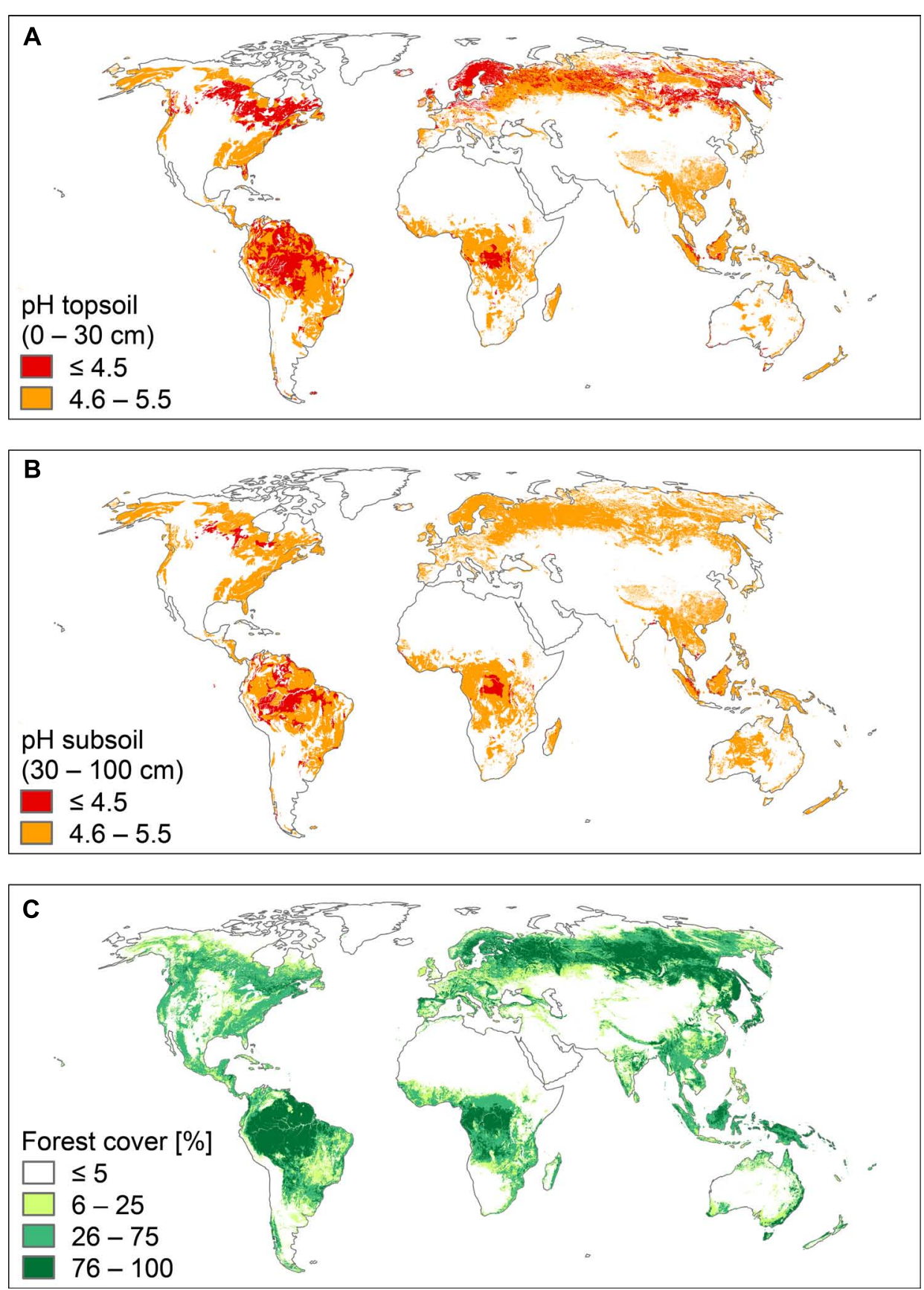

FIGURE 1 | World acid soils and world forests. (A) $\mathrm{pH}$ of topsoil $(0-30 \mathrm{~cm})$, (B) $\mathrm{pH}$ of subsoil $(30-100 \mathrm{~cm})$, and (C) forest cover. Soil pH is presented in two classes: $\mathrm{pH} \leq 4.5$ (strongly acid soils) and $\mathrm{pH} 4.6-5.5$ (moderately acid soils). Data were retrieved from the Harmonized World Soil Data Base
(FAO/IIASA/ISRIC/ISS-CAS/JRC, 2012). Forest cover is presented in four classes: $\leq 5,6-25,26-75$, and $76-100 \%$. Data were retrieved from the Food Insecurity, Poverty and Environment Global GIS Database (FGGD; FAO and IIASA, 2007). from roots, which has been demonstrated to be a major $\mathrm{Al}^{3+}$ resistance mechanism in several plant species (Delhaize et al., 1993, 2007).

Following Ryan and Delhaize (2010) and Horst et al. (2010), the term "Al ${ }^{3+}$ resistance" is used here as a plant property that allows a plant to grow with little or no injury under elevated $\mathrm{Al}^{3+}$ conditions. The potential mechanisms conferring resistance to $\mathrm{Al}^{3+}$ can be broadly divided into those that exclude $\mathrm{Al}^{3+}$ from the root symplast (exclusion mechanisms) and those that enable plants to cope with $\mathrm{Al}^{3+}$ safely, once it enters the symplast (internal tolerance mechanisms; e.g., Kochian, 1995). Exclusion mechanisms depend on the release of ligands which chelate and detoxify $\mathrm{Al}^{3+}$ externally and limit its uptake in the cytosol. Tolerance mechanisms include those that chelate the $\mathrm{Al}^{3+}$ entering 
the root cells, with subsequent transport and sequestration into less sensitive parts of the plant and subcellular compartments. The physiology, biochemistry, and molecular biology of these mechanisms have been thoroughly discussed in several review articles (e.g., Jones and Ryan, 2003; Kochian et al., 2004; Ma, 2007; Poschenrieder et al., 2008; Horst et al., 2010; Ryan et al., 2011; Delhaize et al., 2012; Inostroza-Blancheteau et al., 2012). The proposed principles of these mechanisms are summarized in Figure 2 .

In this paper, we review the literature on proposed $\mathrm{Al}^{3+}$ resistance mechanisms of woody plants. We summarize information obtained from crops and Arabidopsis, and then review relevant results from similar studies in woody plants. In addition, we discuss the occurrence of $\mathrm{Al}$ accumulators and $\mathrm{Al}$ excluders in different forest biomes of the world.

\section{$\mathrm{Al}^{3+}$ EXCLUSION}

\section{RELEASE OF SUBSTANCES THAT CHELATE AND DETOXIFY $\mathrm{Al}^{3+}$}

The best-documented mechanism of $\mathrm{Al}^{3+}$ exclusion is the $\mathrm{Al}^{3+}$ activated efflux of organic acids from roots. Typical organic acids released by plants are citrate, malate, and oxalate. These organic acids are deprotonated anions at the $\mathrm{pH}$ found in the cytosol, and once transported out of the root, they chelate the toxic $\mathrm{Al}^{3+}$ in the rhizosphere, forming stable and non-toxic complexes. Citrate and malate are present in all plant cells because they are involved in the mitochondrial respiratory cycle. Oxalate is a common cellular constituent involved in $\mathrm{Ca}^{2+}$ regulation, ion balance, and metal detoxification (Franceschi and Nakata, 2005; Rahman and Kawamura, 2011). The three organic acid anions form complexes with $\mathrm{Al}^{3+}$ with the following order of strength: citrate $>$ oxalate $>$ malate (Libert and Franceschi, 1987; Jones and Ryan, 2003). Physiological and genetic evidence from several plant species shows that the $\mathrm{Al}^{3+}$-activated efflux of organic acid anions indeed confers resistance to $\mathrm{Al}^{3+}$. The most convincing support comes from genotypes within a species that show contrasting levels of $\mathrm{Al}^{3+}$ resistance. In wheat (Triticum aestivum), for example, a pair of near-isogenic lines that differ in resistance at a single locus was used to show that the $\mathrm{Al}^{3+}$-activated efflux of malate from roots was greater in the resistant genotype than in the sensitive genotype (Delhaize et al., 1993). The same wheat genotypes were used to clone the $\mathrm{Al}^{3+}$-activated malate transporter (TaALMT1) gene, the first $\mathrm{Al}^{3+}$ resistance gene isolated from plants (Sasaki

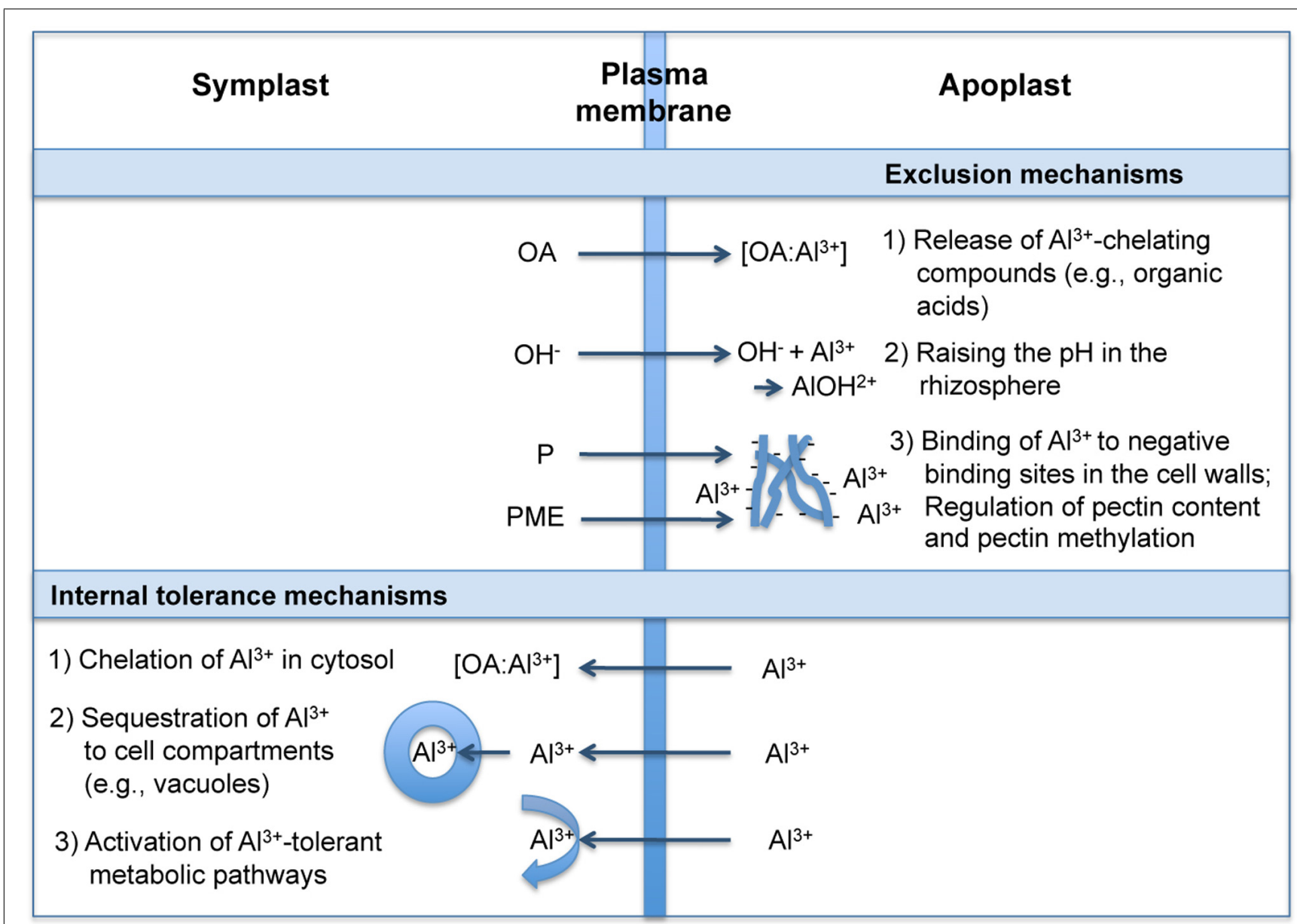

FIGURE 2 | Mechanisms of plant roots to deal with Al ${ }^{3+}$ (modified from Jones and Ryan, 2003; Inostroza-Blancheteau et al., 2012). OA, organic acids; $\mathrm{P}$, pectin; $\mathrm{PME}$, pectin methylesterase. 
et al., 2004). This gene encodes a plasma membrane-bound protein responsible for the efflux of malate from roots. Subsequently, TaALMT1-like genes were isolated from several additional plant species, including Arabidopsis and rape (Brassica napus; Hoekenga et al., 2006; Ligaba et al., 2006; see also Delhaize et al., 2007). Citrate efflux, on the other hand, was found to be mediated by members of another protein family, the multidrug and toxic compound extrusion (MATE) family (Furukawa et al., 2007; Magalhaes et al., 2007). The molecular background of oxalate exudation has not yet been identified.

Numerous studies, some of which are described here, have found that woody plants release organic acid anions following $\mathrm{Al}^{3+}$ exposure. In the model tree poplar (Populus), the $\mathrm{Al}^{3+}$ activated release of organic acid anions has been studied both at the physiological and molecular level. In young rooted cuttings of Populus tremula, $\mathrm{Al}^{3+}$ induces the release of citrate and oxalate (Qin etal., 2007). In a follow-up study with the same poplar clone, Grisel et al. (2010) identified a MATE gene with a $60 \%$ amino acid sequence identity to the AtMATE1 gene of Arabidopsis. The poplar gene is induced by $\mathrm{Al}^{3+}$ in both root and stem tissue, but not in the leaves, consistent with a function of this gene in the efflux of citrate from roots. In seedlings of two other poplar species, Populus tremuloides and Populus trichocarpa, $\mathrm{Al}^{3+}$ induced the exudation of citrate, malate, and oxalate from roots (Naik et al., 2009). In these species, organic acids accounted for $20-64 \%$ of the total $\mathrm{C}$ released upon $\mathrm{Al}^{3+}$ exposure (Naik et al., 2009). The minimal concentrations of $\mathrm{Al}^{3+}$ required to induce organic acid exudation in Populus tremula are between 50 and $100 \mu \mathrm{M} \mathrm{Al}^{3+}$ (Table 1; Qin et al., 2007). Using the same solution culture medium, similar threshold values were found in the two coniferous trees Cryptomeria japonica and Pinus thunbergii (Hirano et al., 2012; Table 1). Although these studies clearly demonstrate that $\mathrm{Al}^{3+}$ induces the release of organic acid anions from roots, direct physiological and genetic evidence for their role in $\mathrm{Al}^{3+}$ resistance has not been established. For example, it is not known whether the organic acid anions are released primarily from the root tip, which would be indicative for a role in $\mathrm{Al}^{3+}$ resistance.

Woody plant species vary considerably in the organic acid compounds they release in response to $\mathrm{Al}^{3+}$ exposure. Many species exude more than one organic acid anion, with various combinations of malate, oxalate, and succinate. In the broad-leaved deciduous and evergreen trees and shrubs assayed so far, citrate is the most common organic acid anion identified (Table 2 and references therein). Of the five coniferous tree species analyzed, three released oxalate, and the two remaining citrate and succinate, respectively (Table 2).

Little is known about other substances that may be released by roots to chelate $\mathrm{Al}^{3+}$. Proposed compounds include polypeptides, phenolic compounds, cyclic hydroxamates, and rhizodepositions in the form of mucilage (Jones and Ryan, 2003; Poschenrieder etal., 2008). In the tea plant, Camellia sinensis, Morita et al. (2011) observed beside of oxalate an increase of the release of caffeine, a phenolic compound, in response to $\mathrm{Al}^{3+}$ exposure. Phenolic compounds were also exuded in $\mathrm{Al}^{3+}$-treated Eucalyptus camaldulensis and two Melaleuca species (Nguyen et al., 2003).
Table 1 | Organic acid release from roots of Cryptomeria japonica $\left(\mu \mathrm{mol} \mathrm{g}^{-1} \mathrm{day}^{-1} \mathrm{FW}\right)$, Pinus thunbergii ( $\left.\mu \mathrm{mol} \mathrm{g}^{-1} \mathrm{day}^{-1} \mathrm{FW}\right)$, and Populus tremula ( $\mu \mathrm{mol} \mathrm{g}^{-1} \mathrm{DW}$ ) after exposition to $\mathrm{Al}^{3+}$ (according to Qin et al., 2007; Hirano et al., 2012).

\begin{tabular}{|c|c|c|c|c|}
\hline Tree species & $\begin{array}{l}\mathrm{Al}^{3+} \text { concen- } \\
\text { tration }(\mu \mathrm{M})\end{array}$ & Citrate & Malate & Oxalate \\
\hline \multirow[t]{5}{*}{ Cryptomeria japonica } & 0 & $0.08^{a}$ & $0.10^{\mathrm{a}}$ & $0.14^{a}$ \\
\hline & 100 & 0.39 & 0.14 & 0.49 \\
\hline & 500 & 0.41 & 0.14 & 0.75 \\
\hline & 1000 & 0.38 & 0.13 & 0.70 \\
\hline & $P$ value $^{b}$ & ns & ns & $*$ \\
\hline \multirow[t]{5}{*}{ Pinus thunbergii } & 0 & $0.03^{a}$ & $0.03^{a}$ & 0.47 \\
\hline & 100 & 0.10 & $0.03^{a}$ & 1.08 \\
\hline & 500 & 0.10 & $0.03^{a}$ & 2.93 \\
\hline & 1000 & 0.11 & $0.03^{a}$ & 4.04 \\
\hline & $P$ value & $*$ & ns & $* *$ \\
\hline \multirow[t]{7}{*}{ Populus tremula } & 0 & $0.0^{\mathrm{a}}$ & $0.0^{\mathrm{a}}$ & 0.1 \\
\hline & 50 & 0.8 & $0.0^{\mathrm{a}}$ & 4.5 \\
\hline & 100 & 1.9 & $0.0^{\mathrm{a}}$ & 3.9 \\
\hline & 200 & 18.4 & $0.0^{\mathrm{a}}$ & 5.6 \\
\hline & 500 & 20.5 & $0.0^{a}$ & 25.7 \\
\hline & 1000 & 20.3 & $0.0^{\mathrm{a}}$ & 18.8 \\
\hline & $P$ value & $* * *$ & ns & $* * *$ \\
\hline
\end{tabular}

a Below detection limit.

${ }^{\mathrm{b}}$ ANOVA: ${ }^{*}{ }^{*} P<0.001,{ }^{*} P<0.01,{ }^{*} P<0.05$; ns, not significant.

\section{RAISING THE pH IN THE RHIZOSPHERE}

According to Kochian etal. (2005), only one study to date has unequivocally demonstrated that raising the $\mathrm{pH}$ in the rhizosphere can protect plants from $\mathrm{Al}^{3+}$. For two distinct classes of $\mathrm{Al}^{3+}$ tolerant Arabidopsis mutants, it was shown that $\mathrm{Al}^{3+}$ resistance is mediated by the exclusion of $\mathrm{Al}^{3+}$ from the root either by exudation of malate and citrate (Larsen et al., 1998) or by $\mathrm{H}^{+}$influx at the root apex (Degenhardt et al., 1998). The $\mathrm{H}^{+}$influx resulted in an increase in the rhizosphere $\mathrm{pH}$, and subsequently in a significant decrease in the $\mathrm{Al}^{3+}$ activity around the root tip. However, there is currently no evidence to support that this mechanism operates in Arabidopsis ecotypes. Whether the roots of woody plants make use of such a mechanism remains elusive.

\section{MODIFICATION OF Al ${ }^{3+}$ BINDING SITES IN THE CELL WALL OF ROOT CELLS}

The cell wall of root cells has been suggested to be a site of both $\mathrm{Al}^{3+}$ toxicity and $\mathrm{Al}^{3+}$ exclusion (Horst et al., 2010). It has been determined that up to $90 \%$ of the $\mathrm{Al}^{3+}$ absorbed by roots can be localized to the apoplast (Kochian, 1995). The primary site of $\mathrm{Al}^{3+}$ binding is probably the pectin matrix, which is largely composed of homopolymers of galacturonic acid (Mohnen, 2008; Horst et al., 2010). $\mathrm{Al}^{3+}$ is known to bind far more strongly to pectin than $\mathrm{Ca}^{2+}$, whose binding to the cell wall is required for proper cell wall functioning (Franco et al., 2004). It has been proposed that $\mathrm{Al}^{3+}$ binds to the cell wall through a replacement of $\mathrm{Ca}^{2+}$, making 
Table $2 \mid \mathrm{Al}^{3+}$-activated release of organic acids from roots of woody plants.

\begin{tabular}{ll}
\hline Plant species & $\begin{array}{l}\mathrm{Al}^{3+} \text {-activated } \\
\text { organic acids }\end{array}$
\end{tabular}

\begin{tabular}{lll}
\hline Non-mycorrhizal roots; coniferous trees & \\
Cryptomeria japonica & Citrate, oxalate & Hirano et al. (2012) \\
Picea abies & Oxalate & Heim et al. (2001) \\
Picea abies & - & Eldhuset et al. (2007) \\
Pinus sylvestris & Oxalate & Ahonen-Jonnarth et al. \\
& & (2000)
\end{tabular}

Pinus thunbergii Citrate, oxalate Hirano etal. (2012)

Non-mycorrhizal roots; broad-leaved trees (deciduous)

$\begin{array}{lll}\text { Populus tremula } & \text { Citrate, oxalate } & \text { Qin etal. (2007) } \\ \text { Populus tremuloides } & \text { Citrate, malate, } & \text { Naik etal. (2009) } \\ & \text { oxalate, succinate } & \\ \text { Populus trichocarpa } & \text { Citrate, malate, } & \text { Naik etal. (2009) } \\ & \text { oxalate, succinate } & \end{array}$

Non-mycorrhizal roots; broad-leaved trees and shrubs (evergreen)
Acacia auriculiformis

Citrate, oxalate

Nguyen et al. (2003)

Camellia sinensis

Oxalate

Camellia sinensis

Cinnamomum camphora

Citrus grandis

Citrus junos

Citrus sinensis

Eucalyptus camaldulensis

Eucalyptus camaldulensis

Eucalyptus cloeziana

Eucalyptus dunnii

Eucalyptus globulus

Eucalyptus grandis

Eucalyptus saligna

Eucalyptus urophylla

$-$

Citrate

Citrate, malate

Citrate

Citrate, malate

Citrate, oxalate

Citrate, oxalate

Citrate

Citrate, malate,

oxalate

Citrate, malate

Silva et al. (2004)

Citrate

Silva et al. (2004)

Citrate

Citrate, malate,

Silva et al. (2004)

oxalate

Melaleuca bracteata

Melaleuca cajuputi

Citrate

Tahara et al. (2008)

Melaleuca cajuputi

Citrate, malate

Tahara et al. (2008)

Citrate, oxalate

Nguyen etal. (2003)

Melaleuca leucadendra

Citrate

Nguyen et al. (2003)

\section{Mycorrhizal roots}

Picea abies

Succinate

Heim et al. (2003)

Picea abies

Pinus densiflora

$-$

Pinus sylvestris

Citrate

Eldhuset et al. (2007)

Oxalate
Tahara et al. (2005)

Ahonen-Jonnarth et al.
The references are divided into studies dealing either with non-mycorrhizal roots or with mycorrhizal roots. the cell wall more rigid, and thus reducing its extensibility which is required for normal cell elongation (Tabuchi and Matsumoto, 2001).

Several studies have suggested that the pectin content and the degree of pectin methylation are important determinants of the amount of $\mathrm{Al}^{3+}$ that can bind to the cell wall of root cells. In maize (Zea mays), rice (Oryza sativa), and common bean (Phaseolus vulgaris), differences in the pectin content and/or the degree of pectin methylation were linked with $\mathrm{Al}^{3+}$ sensitivity/resistance (Eticha et al., 2005; Yang et al., 2008; Rangel et al., 2009). $\mathrm{Al}^{3+}$ resistant lines of all three plant species were found to have a higher degree of pectin methylation, and a lower cell wall Al content when compared to $\mathrm{Al}^{3+}$-sensitive lines, supporting a role for pectin methylation in $\mathrm{Al}^{3+}$ exclusion. A modulating role for the degree of pectin methylation is further supported by the finding that the expression of pectin methylesterase (PME), the enzyme responsible for the demethylation of pectin, was lower in $\mathrm{Al}^{3+}{ }_{\text {-resistant }}$ lines than in $\mathrm{Al}^{3+}$-sensitive lines (Maron et al., 2008; Yang et al., 2008).

Current evidence, based on X-ray microanalyses, indicates that the apoplast is a major site of $\mathrm{Al}$ accumulation also in woody plants. In $\mathrm{Al}^{3+}$-treated seedlings of the conifer Picea abies, $\mathrm{Al}$ was found in both epidermal and cortical cells of the root tip (Heim et al., 1999). In both cell types, more than $88 \%$ of the total $\mathrm{Al}$ localized to the cell wall. In addition, it was observed that the amount of $\mathrm{Ca}$ in the cell wall of both cell types was much lower in $\mathrm{Al}^{3+}$-treated seedlings than in control plants, suggesting that $\mathrm{Al}^{3+}$ replaced $\mathrm{Ca}^{2+}$ at the exchange sites of the cell wall. These findings are further substantiated by results of a study conducted in Picea abies and Populus tremula, cultivated in a model ecosystem for 3 years (Brunner et al., 2008). In Picea abies, Al accumulated continuously over time in the cell wall of root epidermal cells, whereas in Populus tremula, $\mathrm{Al}$ accumulated in the cell wall of both root epidermal and cortical cells. In both species, $\mathrm{Al}$ did not accumulate intracellularly (Table 3 ).

In root cells of woody plants, little evidence exists about the relationship between cell wall polysaccharides and $\mathrm{Al}^{3+}$ sensitivity/resistance. In a set of poplar clones, representing several interspecific crosses, it was found that the $\mathrm{Al}$ content of the root symplast was higher in $\mathrm{Al}^{3+}$-resistant clones than in $\mathrm{Al}^{3+}$-sensitive clones (Smith et al., 2011). The Al content of the root symplast, on the other hand, was lower in $\mathrm{Al}^{3+}{ }_{\text {-resistant clones than in }}$ $\mathrm{Al}^{3+}$-sensitive clones. This pattern of cellular Al distribution suggests that the cell wall of root cells prevented $\mathrm{Al}^{3+}$ from entering the root symplast. Additional parameters investigated were pectin and callose, the latter of which is a widely used indicator of early $\mathrm{Al}^{3+}$ toxicity symptoms (Hirano et al., 2004, 2012; Kochian et al., 2005). Treatment with $\mathrm{Al}^{3+}$ increased pectin and callose levels in all clones, but more prominently in $\mathrm{Al}^{3+}$-sensitive clones. A clear conclusion about the impact of pectin could not be drawn because the degree of pectin methylation was not assessed.

\section{$\mathrm{Al}^{3+}$ TOLERANCE CHELATION OF Al ${ }^{3+}$ WITH ORGANIC SUBSTANCES IN THE CYTOSOL}

Organic acid anions and phenolic compounds have also been implicated in internal $\mathrm{Al}^{3+}$ tolerance. Once $\mathrm{Al}^{3+}$ enters the cell, the concentration of free $\mathrm{Al}^{3+}$ cations in the cytosol will be very 
low, but even at these concentrations, $\mathrm{Al}^{3+}$ remains a hazard. The very high affinity of $\mathrm{Al}^{3+}$ for oxygen ligands allows it to compete with other ions for metabolically important sites despite a large disparity in their concentrations (Jones and Ryan, 2003).

Indeed, studies of several woody plant species demonstrate that intracellular $\mathrm{Al}^{3+}$ is chelated by organic acid anions. In the small shrub Melastoma malabathricum, upon entering the root, $\mathrm{Al}^{3+}$ binds to citrate, and the Al-citrate complex itself is transported from the root to the shoot (Watanabe and Osaki, 2001). In the leaves, the $\mathrm{Al}$-citrate complex is transformed into Al-oxalate $1: 1$, $1: 2$, and 1:3 complexes. The former two complexes are potentially toxic to the plant. A similar transformation of $\mathrm{Al}$-organic acid complexes is described for the tea plant. Upon entering the root cell, $\mathrm{Al}^{3+}$ binds to oxalate and then is transported from the root to the shoot in the form of Al-citrate and Al-malate complexes (Morita et al., 2004, 2008). In a comparison of several Eucalyptus species, the concentration of root tip malate was found to correlate positively with the degree of $\mathrm{Al}^{3+}$ resistance in the presence of $\mathrm{Al}^{3+}$ (Silva et al., 2004). In contrast, in the poplar clones of the above-mentioned study, the concentrations of symplastic citrate and formate correlated closely with $\mathrm{Al}^{3+}$ sensitivity (Smith et al., 2011).

Besides organic acids, there are other complex forming compounds, e.g., phenolic substances, that bind $\mathrm{Al}^{3+}$ in the cytosol. For example, in the tea plant, Al-catechin complexes were described (Nagata et al., 1992). In the sepals of the small shrub Hydrangea macrophylla, $\mathrm{Al}^{3+}$ is bound to both 3-caffeoylquinic acid and delphinidin 3-glucoside, where $\mathrm{Al}^{3+}$ is thought to play a role in stabilizing the two organic compounds, and thus causing the color to change from red to blue (Ma et al., 2001). In the root apices of the camphor tree (Cinnamomum camphora), an accumulation of proanthocyanidin, which is composed of flavan-3-ols (e.g., catechin), has been demonstrated (Osawa et al., 2011). An increase in root phenolics has been observed by Ofei-Manu et al. (2001) in a series of woody plants upon $\mathrm{Al}^{3+}$ exposure, including Camellia sinensis, Cryptomeria japonica, E. viminalis, Gleditsia triacanthos, Picea abies, Pinus densiflora, Pinus thunbergii, Populus tremuloides, Robinia pseudoacacia, and Rhus succedanea.

\section{SEOUESTRATION OF AI ${ }^{3+}$ TO METABOLICALLY LESS SENSITIVE COMPARTMENTS}

The uptake and storage of high $\mathrm{Al}^{3+}$ concentrations in aerial parts of the plant is a trait common to many plant species of tropical regions, where the ability to cope with $\mathrm{Al}^{3+}$ stress is a strong prerequisite for survival (Ryan and Delhaize, 2010). Plants that accumulate $>1 \mathrm{mg} \mathrm{g}^{-1}$ DW Al are considered Alhyperaccumulators (Jansen etal., 2002). Plant families with woody Al-hyperaccumulators storing very large amounts of $\mathrm{Al}$ (>10 $\mathrm{mg} \mathrm{g}^{-1}$ DW) in their leaves include Melastomataceae, Rubiaceae, and Theaceae (Matsumoto et al., 1976; Watanabe et al., 1997; Masunaga etal., 1998; Jansen et al., 2003; Olivares et al., 2010; Gonzalez-Santana et al., 2012).

A typical example of a woody plant capable of accumulating large amounts of $\mathrm{Al}\left(>15 \mathrm{mg} \mathrm{g}^{-1}\right)$ in its leaves is the tree species Richeria grandis from the Venezuelan cloud forest. Using X-ray microanalysis, Cuenca et al. (1991) showed that Al is stored extracellularly in the cell wall of mature leaves. Further extracellular cell wall storage of $\mathrm{Al}$ was demonstrated in the woody Al-hyperaccumulators Camellia sinensis, Conostegia xalapensis, Faramea marginata, and Melastoma malabathricum. The cell wall of the epidermal and the mesophyll cells of the leaves were the main sites for $\mathrm{Al}$ accumulation (Watanabe and Osaki, 2001; Britez et al., 2002; Tolra et al., 2011; Gonzalez-Santana et al., 2012). Interestingly, the chloroplasts of Qualea grandiflora and Callisthene major, two Al-hyperaccumulating woody plant species from the Vochysiaceae family, which grow in the Brazilian Cerrado, have been suggested as a primary compartment for $\mathrm{Al}$ sequestration (De Andrade et al., 2011). $\mathrm{Al}^{3+}$ can also be sequestered into cells specialized for storage functions, e.g., idioblasts containing Ca-oxalate crystals have been considered as a location for $\mathrm{Al}^{3+}$ detoxification in the leaves of Corchorus olitorius (Mazen, 2004).

Table 3 | Al accumulation in fine roots of Picea abies and Populus tremula [Al concentrations of bulk material; Al net counts of compartments using, energy-dispersive X-ray spectroscopy (EDX)-analyses] after growth in weakly acidic soil (pH 6.5) with different length of exposition time (according to Brunner et al., 2008).

\begin{tabular}{|c|c|c|c|c|c|c|}
\hline \multirow[t]{2}{*}{ Tree species } & \multirow[t]{2}{*}{ Time (year) } & \multirow{2}{*}{$\begin{array}{l}\text { Al concentration } \\
\left(\mathrm{mg} \mathrm{g}^{-1}\right)\end{array}$} & \multicolumn{2}{|c|}{ Al counts in epidermal cells } & \multicolumn{2}{|c|}{ Al counts in cortical cells } \\
\hline & & & Cell wall & Intracellular & Cell wall & Intracellular \\
\hline & 1.5 & 8.23 & 284 & 73 & 122 & 72 \\
\hline & 2.5 & 9.50 & 355 & 101 & 140 & 80 \\
\hline \multirow[t]{4}{*}{ Populus tremula } & 0.5 & 1.81 & 168 & 67 & 96 & 65 \\
\hline & 1.5 & 16.40 & 359 & 50 & 152 & 51 \\
\hline & 2.5 & 5.36 & 338 & 57 & 163 & 63 \\
\hline & $P$ value & $-\mathrm{b}$ & $* * *$ & ns & $* *$ & ns \\
\hline
\end{tabular}

\footnotetext{
a Repeated measures ANOVA: ${ }^{*}{ }^{*} P<0.001,{ }^{*} P<0.01,{ }^{*} P<0.05$, ns, not significant
}

${ }^{b}$ No statistical analysis possible because of missing replicates. 
Transport of $\mathrm{Al}$ from the root to the shoot is likely to involve complexes of $\mathrm{Al}$ with organic acids (see above). Little is known about the transport of $\mathrm{Al}$ across the plasma membrane and further sequestration into subcellular compartments. Transport across membranes requires transport proteins. Candidates for such proteins have been identified in the $\mathrm{Al}^{3+}$-sensitive mutants als 1 and als 3 of Arabidopsis. Both mutants are mutated in genes encoding proteins that belong to the ATP-binding cassette (ABC) transporter superfamily. ALS1 ( $\mathrm{Al}^{3+}$-sensitive) is a half type $\mathrm{ABC}$ transporter, whereas ALS3 is an ABC transporter-like protein, lacking the ABC domain. The functions and substrates of ALS1 and ALS3 are not known, but the mutant phenotypes, the subcellular localization of the proteins, and tissue-specific gene expression have led to the assumption that the two proteins sequester and transport $\mathrm{Al}^{3+}$ to overcome $\mathrm{Al}^{3+}$ toxicity. ALS1 is likely to be involved in the intracellular transport of $\mathrm{Al}^{3+}$ to vacuoles of root tip cells and cells of the plant vasculature (Larsen et al., 2007). ALS3 is mainly localized to the plasma membrane of root cortex cells and phloem cells throughout the plant, suggesting that it mediates the intercellular redistribution of accumulated $\mathrm{Al}$ away from sensitive tissues (Larsen et al., 2005). In Populus tremula, Grisel et al. (2010) identified an ALS3-like gene with a 79\% amino acid sequence identity with the Arabidopsis ALS3 gene. The poplar gene was found to be expressed in the root, stem, and leaves, and was strongly induced by $\mathrm{Al}^{3+}$ in the root (44-fold; Figure 3A). In addition, the poplar gene was inducible by $\mathrm{Al}^{3+}$, but not by $\mathrm{La}^{3+}$ (lanthanum; Figure 3B), consistent with the finding that the Arabidopsis mutant als 3 is not affected by $\mathrm{La}^{3+}$ (Larsen et al., 1997).

\section{ACTIVATION OF METABOLIC PATHWAYS TO OVERCOME THE TOXIC EFFECTS OF $\mathrm{Al}^{3+}$}

Moderate $\mathrm{Al}^{3+}$ concentrations are not fatal, and roots may at least partially recover (see also Matsumoto and Motoda, 2012). This is well documented in Populus tremula treated with either no $\mathrm{Al}^{3+}$ or increasing concentrations of $\mathrm{Al}^{3+}$ up to $1,000 \mu \mathrm{M}$. Two phases of root growth could be distinguished: a rapid $\mathrm{Al}^{3+}$-induced growth inhibition (within $6 \mathrm{~h}$ at $\mathrm{Al}^{3+}$ concentrations $>250 \mu \mathrm{M}$ ) and a subsequent phase of growth recovery (within 2 days at $\mathrm{Al}^{3+}$ concentrations $\leq 500 \mu \mathrm{M}$; Grisel et al., 2010). The root growth of plants treated with $1,000 \mu \mathrm{M} \mathrm{Al}^{3+}$ further decreased. This pattern of root growth recovery may reflect the success of the roots in activating metabolic pathways to overcome the toxic effects of $\mathrm{Al}^{3+}$ and/or $\mathrm{Al}^{3+}$ resistance mechanisms. Matsumoto and Motoda (2013) suggested that the recovery of roots exposed to $\mathrm{Al}^{3+}$ is associated with the reduction of $\mathrm{Al}^{3+}$-induced oxidative stress. In Populus tremula, two genes of the oxidative stress pathway (a peroxidase gene and an alternative oxidase gene) were strongly induced upon $\mathrm{Al}^{3+}$ exposition after $6 \mathrm{~h}$ (>8-fold), while their expression decreased to control levels after 2 days (Grisel et al., 2010).

Two additional genes of Populus tremula that may play a role in root growth recovery encode CorA-like $\mathrm{Mg}^{2+}$ transporters (Grisel et al., 2010). These genes were induced up to fivefold by $\mathrm{Al}^{3+}$. The activity of a homologous CorA-like $\mathrm{Mg}^{2+}$ transporter from Arabidopsis was shown to be blocked by micromolar concentrations of $\mathrm{Al}^{3+}$, when expressed in bacteria (Li et al., 2001). In

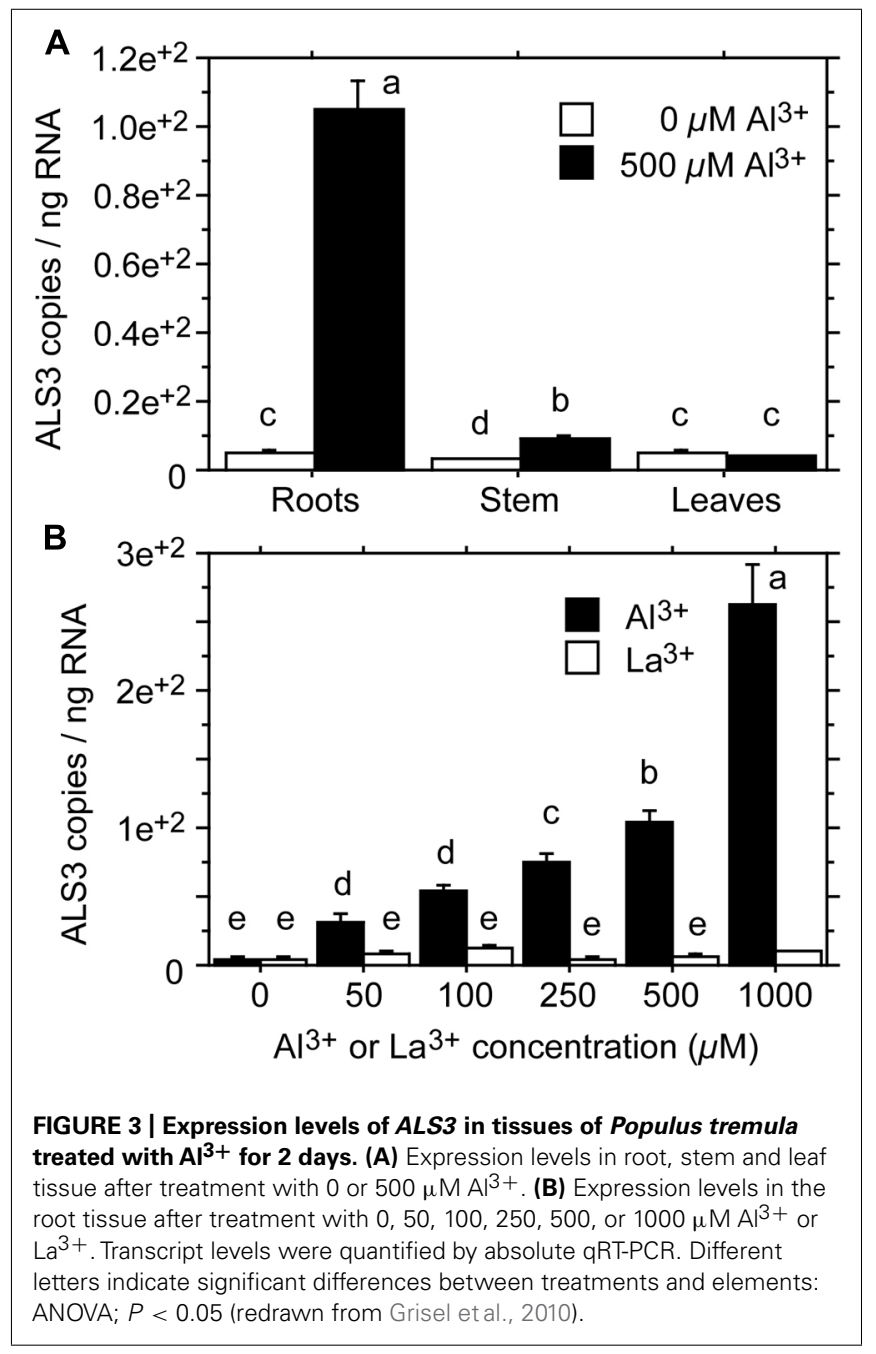

addition, the same CorA-like $\mathrm{Mg}^{2+}$ transporter alleviated $\mathrm{Al}^{3+}$ toxicity when overexpressed in planta (Deng et al., 2006). $\mathrm{Mg}^{2+}$ has been reported to be able to alleviate $\mathrm{Al}^{3+}$ toxicity in a number of crop plants (see reviews of Bose et al., 2011; Chen and Ma, 2013). Various mechanisms have been put forward to explain how $\mathrm{Mg}^{2+}$ can alleviate $\mathrm{Al}^{3+}$ toxicity. These mechanisms include increased ionic strength of the solutions, reduction in $\mathrm{Al}^{3+}$ saturation at the apoplastic exchange sites, and decreased $\mathrm{Al}^{3+}$ activity at the root cell plasma membrane surface (Bose et al., 2011). However, the identified $\mathrm{Mg}^{2+}$ transporters indicate that, besides of electrostatic interactions, biochemical processes may be involved in the rescue of $\mathrm{Al}^{3+}$ toxicity.

\section{ADAPTATIONS}

The tropical forests and the forests of boreal and temperate regions have evolved on geological timescales under very different conditions. The forests of boreal and temperate regions were repeatedly affected by the Pleistocene glaciations, while the impact of the Pleistocene climatic fluctuations was certainly much less severe in tropical regions. Most tropical forests have not been disturbed for hundred thousands of years, and thus typically grow on highly 
weathered soils, which are strongly acidic, both in the topsoil and the subsoil (Figures 1A,B).

Accumulating evidence shows that in tropical regions both $\mathrm{Al}$ excluders and $\mathrm{Al}$ accumulators occur. Examples of woody species that are strong excluders are Melaleuca cajuputi, Acacia mangium, and Leucaena leucocephala (Osaki et al., 1997), which are all capable of exuding organic acid anions from their roots (see also Table 2). Examples of woody species that store high amounts of $\mathrm{Al}$ in leaves are Melastoma malabathricum and $H$. macrophylla. Other woody species, such as Vaccinium macrocarpon, store high amounts of $\mathrm{Al}$ in their roots (Osaki et al., 1997). Most Al-hyperaccumulator plants are shrub-type broad-leaved woody plants.

Phylogenetic analyses indicate that $\mathrm{Al}$ hyperaccumulation is a trait that has arisen a number of times, and this trait is scattered over more than 20 orders across about 45 families belonging to magnoliids (e.g., Laurales), eudicots (e.g., Proteales), rosids (e.g., Malpighiales, Myrtales), and asterids (e.g., Gentianales, Ericales; Table 4; Jansen et al., 2002). To date, Al accumulation in tall trees has only been found in a few tree species of the Euphorbiaceae (Osawa et al., 2013). The predominance of $\mathrm{Al}$ accumulators within non-flowering plants suggests that $\mathrm{Al}$ accumulation evolved early in the evolution of land-plants and is probably a primitive characteristic associated with survival in ancient $\mathrm{Al}^{3+}$-rich environments (Jansen et al., 2002).

An analysis of the variation in foliar $\mathrm{Al}$ and macronutrient concentrations in a global dataset of plant species in a phylogenetic framework showed that the frequency distribution of foliar $\mathrm{Al}$ concentration in tropical regions clearly had two peaks ("bimodal"), whereas in temperate regions it showed only one peak ("unimodal"; Metali et al., 2012). This conclusion supports the hypothesis that $\mathrm{Al}$ accumulators and non- $\mathrm{Al}$ accumulators exist as distinct, but overlapping, groups of species. The estimated threshold value of foliar $\mathrm{Al}$ concentrations that distinguishes $\mathrm{Al}$ accumulators from non-Al accumulators varies geographically. The foliar threshold of tropical plants is higher (2.3-3.9 $\left.\mathrm{mg} \mathrm{g}^{-1}\right)$ than that of temperate plants $\left(1.1 \mathrm{mg} \mathrm{g}^{-1}\right.$; Metali et al., 2012). Among angiosperm species, there was a significant phylogenetic signal in foliar Al concentrations, substantiating results of previous studies, suggesting a greater prevalence of $\mathrm{Al}$

Table 4 | Families of woody plants with strong and/or numerous Al-hyperaccumulators (according to Jansen et al., 2002).

\begin{tabular}{lll}
\hline Clade & Order & Family \\
\hline Magnoliids & Laurales & $\begin{array}{l}\text { Lauraceae, Monimiaceae, } \\
\text { Siparunaceae }\end{array}$ \\
Eudicots & Proteales & Proteaceae \\
Eurosids I & Malpighiales & Euphorbiaceae \\
Eurosids II & Myrtales & Crypteroniaceae, Melastomataceae, \\
& & Vochysiaceae \\
Asterids & Ericales & Diapensiaceae, Symplocaceae, \\
& & Ternstroemiacieae, Theaceae \\
Euasterids I & Gentianales & Rubiaceae
\end{tabular}

accumulators in some families than in others (e.g., Jansen et al., 2002, 2003). A phylogenetical signal may also arise when related species occupy relatively similar habitats that differentially influence nutrient uptake and accumulation (Thompson et al., 1997). For example, Schreeg et al. (2010) have provided evidence for significant associations between high soil Al and Mn concentrations and the distributions of trees in the Vochysiaceae and Myrtaceae on a 50-ha plot in a semideciduous moist forest in Panama.

Compared to soils of tropical regions, soils of boreal and temperate regions are generally younger, although large areas, such as Siberia and Beringia, were ice-free during the Last Glacial Maximum (26,500-18,000 year before present; Clark et al., 2009). However, soils of these ice-free areas were severely affected by cold climate and permafrost, strongly limiting soil chemical and soil biological processes. As a consequence, soils in boreal and temperate regions are generally less weathered and thus less acidic than tropical soils, particularly in the subsoil (Figure 1B). In contrast, topsoils of the boreal regions are highly acid due to the strong acidifying effect of the coniferous litter during the incomplete decomposition process and the formation of humic acids (Schachtschabel et al., 1992).

Aluminum concentrations measured in roots from temperate or boreal woody species suggest, that the immobilization of $\mathrm{Al}^{3+}$ in the cell wall is most likely an important adaptation. Al concentrations in the fine roots of common temperate and boreal woody species usually exceed the limit for being hyperaccumulators $\left(>1 \mathrm{mg} \mathrm{g}^{-1}\right)$. For example fine roots of Abies alba, Castanea sativa, Fagus sylvatica, Picea abies, Pinus cembra, and Pinus montana all have values of 1-10 $\mathrm{mg} \mathrm{g}^{-1}$ DW (Zysset et al., 1996; Brunner et al., 2002; Genenger et al., 2003; Hirano et al., 2006; Richter et al., 2011; see also Table 3). All these woody species are ectomycorrhizal, suggesting that ectomycorrhizal structures, such as fungal mantle and Hartig net, further contribute to the accumulation of $\mathrm{Al}$ in roots by immobilizing $\mathrm{Al}$ in the cell wall of the fungal hyphae (Brunner and Frey, 2000; Heim et al., 2003) or in the fungal vacuoles (Martin et al., 1994). Ectomycorrhizas in temperate and boreal regions have, we assume, the function not only to take up water and nutrients but also to immobilize toxic $\mathrm{Al}^{3+}$. Because ectomycorrhizal trees and ericoid-mycorrhizal Ericales dominate in temperate and boreal regions, we propose that this mechanism to immobilize $\mathrm{Al}^{3+}$ is a major mechanism for excluding $\mathrm{Al}^{3+}$ from the roots of woody plants in these regions, a suggestion first proposed by Jansen et al. (2002). Moreover, mycorrhizal fungi may well contribute significantly to the cycling of $\mathrm{Al}$ in forest ecosystem because high concentrations of $\mathrm{Al}$ can be found in their fruiting bodies (Smits and Hoffland, 2009). An additional adaptation of tree roots from temperate or boreal forests to acid soils is the observation that the roots have a shorter lifespan, which means that the turnover rate of roots exposed to elevated $\mathrm{Al}^{3+}$ concentrations is higher (Godbold et al., 2003; Leuschner et al., 2004; Richter et al., 2013). Reasons for a shorter lifespan could be that Al accumulation has reached its saturation point faster compared to roots from non-acid soils, causing the root to die earlier.

Some woody plants in temperate regions have not evolved strategies to deal with high levels of $\mathrm{Al}^{3+}$ and thus are not adapted to acid soils. Examples are the two species Fraxinus excelsior and 
Acer pseudoplatanus, which both are not ectomycorrhizal. They grow mainly on forest sites with high $\mathrm{pH}$ and high base saturation, and are unlikely to occur on very acid soils (Weber-Blaschke et al., 2002). In a recent study, Walthert et al. (2013) showed that Fraxinus excelsior and Acer pseudoplatanus respond much more sensitively to soil properties than Fagus sylvatica does. The soil properties limiting their distribution are $\mathrm{Al}$ in the case of Fraxinus excelsior, and $\mathrm{Al}$ together with nutrient availability (C/N ratio) in the case of Acer pseudoplatanus. On the contrary, no soil-induced distribution limits were detectable for Fagus sylvatica (Walthert et al., 2013).

Differences in $\mathrm{Al}^{3+}$ resistance not only exist among different tree species but also among local populations of the same species. Kidd and Proctor (2000) assessed the level of $\mathrm{Al}^{3+}$ resistance in four populations of Betula pendula growing on soils that differ in soil acidity and levels of $\mathrm{Al}^{3+}$. Using a solution culture system which simulates natural soil solutions, the authors found that seedlings originating from populations from acid mineral soils ( $\mathrm{pH} 4.3, \mathrm{Al}^{3+}$ concentration $21.1 \mathrm{mg} \mathrm{l}^{-1}$ ), had a significant higher level of $\mathrm{Al}^{3+}$ resistance (measured with the root elongation rate) compared to seedlings from populations from non-acid soils $\left(\mathrm{pH}>4.8, \mathrm{Al}^{3+}<5.3 \mathrm{mg} \mathrm{l}^{-1}\right)$. A similar study was performed by Wilkins and Hodson (1989) who analyzed two populations of Picea abies growing on an acid mineral soil and a calcareous soil, respectively. The growth of seedlings from the acid soil was slightly stimulated by the $\mathrm{Al}^{3+}$ treatment, whereas the growth of that from the calcareous soil was greatly reduced. The results of these studies suggest that high $\mathrm{Al}^{3+}$ soil conditions are a significant force for population divergence due to strong selective pressure associated with adaptation.

Further evidence for population adaptation to acid soil conditions comes from a study of Pinus contorta growing along a steep gradient of soil acidity at the northern coast of California (Eckert et al., 2012). In this area, five well-developed marine terraces exist, whose soils represent a chronosequence ranging from fertile soils close to the coast to podzolic soils with low $\mathrm{pH}$ and high $\mathrm{Al}^{3+}$ concentrations about $5 \mathrm{~km}$ inland (Westman, 1975). Pinus contorta is one of three conifers that have colonized and diversified on the extreme podzolic soils. Shore pine (Pinus contorta ssp. contorta) is found along the lower terraces, while Bolander pine (Pinus contorta ssp. bolanderi), which has a pigmy growth habit, is endemic to the upper marine terraces. Using a candidate gene approach, Eckert et al. (2012) investigated the molecular basis for the colonization of the podzolic soils by Pinus contorta populations. Patterns of nucleotide diversity were analyzed in genes that are related to growth or response to several soil parameters,

\section{REFERENCES}

Ahonen-Jonnarth, U., van Hees, P. A. W., Lundström, U. S., and Finlay, R. D. (2000). Organic acids produced by mycorrhizal Pinus sylvestris exposed to elevated aluminium and metal concentrations. New Phytol. 146, 557567. doi: $10.1046 /$ j.1469-8137.2000. 00653.x

such as $\mathrm{Al}^{3+}, \mathrm{BC}$, and phosphate. The majority of the 21 genes analyzed did not or only weakly deviate from neutrality in patterns of nucleotide diversity. However, two of the genes carried clear signatures of positive selection: one was a putative homolog of the Arabidopsis ALS3 gene and the other an inorganic phosphate transporter gene. The ALS3 gene was characterized by a derived non-synonymous mutation, which is extremely rare in populations of the lower terraces and almost or completely fixed in those of the higher terraces. The phosphate transporter gene included two highly divergent haplotypes, whose frequency differed among lower and higher terraces. The results of this study shed light on some of the genetic components underlying adaptation to local soil conditions along this unique environmental gradient.

\section{CONCLUSION}

Current evidence indicates that woody plants native to acid soils have evolved various strategies to overcome $\mathrm{Al}^{3+}$ stress. These strategies include exclusion of $\mathrm{Al}^{3+}$ from the root tip, probably through the release of organic acid anions. The formation of ectomycorrhizal structures, which are capable of accumulating $\mathrm{Al}$ in the cell wall of hyphal cells, may also be regarded as an exclusion strategy, reducing the degree of contact of root cells to $\mathrm{Al}^{3+}$. Internal strategies rely on the transport and sequestration of $\mathrm{Al}$ in aerial parts of the plant, where the $\mathrm{Al}$ may be stored in the cell wall of different leaf tissues, or in subcellular compartments, like chloroplasts or possibly vacuoles. Some woody plant species may also store high levels of $\mathrm{Al}$ in the cell wall of root cells. The biochemical and molecular mechanisms underlying these strategies, however, remain largely to be determined. The few studies performed so far in woody plants provide hints in which direction research may focus. With the exception of poplar, forest trees are generally not amenable to genetic engineering for testing the impact of candidate genes. Similarly, progenies of controlled crosses, which are valuable for testing segregation of specific traits and genes, exist only for a few tree species. An alternative approach would involve the identification of genes that play a role in adaptation through association of genetic variation with particular soil $\mathrm{Al}^{3+}$ conditions. This has already been initiated and has provided insights into the mechanisms of population adaptation to $\mathrm{Al}^{3+}$-rich environments.

\section{ACKNOWLEDGMENTS}

We thank the reviewers for giving valuable comments on the manuscript. And we thank Silvia Dingwall for correcting and improving the English text. Some of the forest sites cited in this review paper belong to the Long-Term Forest Ecosystem Research Programme LWF of Switzerland.

plants. J. Exp. Bot. 62, 2251-2264 doi: $10.1093 /$ jxb/erq456

P., Zysset, M., Zimmerman S., and Luster, J. (1999). Soil acidification in southern Switzerland between 1987 and 1997: a case study based on the critical load concept. Environ. Sci. Technol. 33, 2383-2389. doi: $10.1021 /$ es 9808144

Bose, J., Babourina, O., and Rengel, Z. (2011). Role of magnesium in alleviation of aluminium toxicity in
Britez, R. M., Watanabe, T., Jansen, S., Reissmann, C. B., and Osaki, M. (2002). The relationship between aluminum and silicon accumulations in leaves of Faramea marginata (Rubiaceae). New Phytol. 156, 437-444. doi: 10.1046/j.1469-8137. 2002.00531.x
Brunner, I., Brodbeck, S., and Walthert, L. (2002). Fine root chemistry, starch concentration, and 'vitality' of subalpine conifer forests in relation to soil pH. For. Ecol. Manag. 165, 75-84. doi: 10.1016/S0378-1127(01) 00633-8

Brunner, I., and Frey, B. (2000). Detection and localization of aluminum and heavy metals in ectomycorrhizal 
Norway spruce seedlings. Environ. Pollut. 108, 121-128. doi: 10.1016/S0269-7491(99)00248-1

Brunner, I., Luster, J., GünthardtGoerg, M. S., and Frey, B. (2008). Heavy metal accumulation and phytostabilisation potential of tree fine roots in a contaminated soil. Environ. Pollut. 152, 559-568. doi: 10.1016/j.envpol.2007.07.006

Brunner, I., Zimmermann, S., Zingg, A., and Blaser, P. (2004). Woodash recycling affects forest soil and tree fine-root chemistry and reverses soil acidification. Plant Soil 267, 61-71. doi: 10.1007/s11104-0054291-Z

Chen, Z. C., and Ma, J. F. (2013). Magnesium transporters and their role in $\mathrm{Al}$ tolerance in plants. Plant Soil. doi: 10.1007/s11104-0121433-y.

Clark, P. U., Dyke, A. S., Shakun, J. D., Carlson, A. E., Clark, J., Wohlfarth, B., et al. (2009). The last glacial maximum. Science 325, 710-714. doi: 10.1126/science. 1172873

Cronan, C. S., and Grigal, D. F. (1995). Use of calcium/aluminum ratios as indicators of stress in forest ecosystems. J. Environ. Qual. 24, 209-226. doi: 10.2134/jeq1995. $00472425002400020002 x$

Cronan, C. S., and Schofield, C. L. (1979). Aluminum leaching response to acid precipitation: effects on highelevation watersheds in the Northeast. Science 204, 304-306. doi: 10.1126/science.204.4390.304

Cuenca, G., Herrera, R., and Merida, T. (1991). Distribution of aluminum in accumulator plants by $\mathrm{X}$-ray microanalysis in Richeria grandis Vahl leaves from a cloud forest in Venezuela. Plant Cell Environ. 14, 437-441. doi: 10.1111/j.13653040.1991.tb00954.x

De Andrade, L. R. M., Gomes Barros, L. M., Echevarria, G. F., do Amaral, L. I. V., Cotta, M. G., Rossatto, D. R. et al. (2011). Al-hyperaccumulator Vochysiaceae from the Brazilian Cerrado store aluminum in their chloroplasts without apparent damage. Environ. Exp. Bot. 70, 3742. doi: 10.1016/j.envexpbot.2010. 05.013

Degenhardt, J., Larsen, P. B., Howell, S. H., and Kochian, L. V. (1998). Aluminum resistance in the Arabidopsis mutant alr-104 is caused by an aluminum-induced increase in rhizosphere pH. Plant Physiol. 117, 19-27. doi: 10.1104/pp.117.1.19

Delhaize, E., Gruber, B. D., and Ryan, P. R. (2007). The roles of organic anion permeases in aluminium resistance and mineral nutrition. FEBS Lett. 581, 2255-2262. doi: 10.1016/j.febslet.2007.03.057

Delhaize, E., Ma, J. F., and Ryan, P. R. (2012). Transcriptional regulation of aluminium tolerance genes. Trends Plant Sci. 17, 341-348. doi: 10.1016/j.tplants.2012.02.008

Delhaize, E., Ryan, P. R., and Randall, P. J. (1993). Aluminum tolerance in wheat (Triticum aestivum L.). II. Aluminum-stimulated excretion of malic acid from root apices. Plant Physiol. 103, 695-702.

Deng, W., Luo, K., Li, Z., Yang, Y., Hu, N., and Wu, Y. (2009). Overexpression of Citrus junos mitochondrial citrate synthase gene in Nicotiana benthamiana confers aluminium tolerance. Planta 230, 355-365. doi: 10.1007/s00425-009-0945-Z

Deng, W., Luo, K., Li, D., Zheng, X., Wei, X., Smith, W., et al. (2006). Overexpression of an Arabidopsis magnesium transport gene, AtMGT1, in Nicotiana benthamiana confers Al tolerance. J. Exp. Bot. 57, 4235-4243. doi: 10.1093/jxb/erl201

Eckert, A. J., Shahi, H., Datwyler, S. L., and Neale, D. B. (2012). Spatially variable natural selection and the divergence between parapatric subspecies of lodgepole pine (Pinus contorta, Pinaceae). Am. J. Bot. 99, 1323-1334. doi: 10.3732/ajb. 1200055

Eldhuset, T. D., Swensen, B., Wickstrøm, T., and Wollebæk, G. (2007). Organic acids in root exudates from Picea abies seedlings influenced by mycorrhiza and aluminium. J. Plant Nutr. Soil Sci. 170, 645-648. doi: 10.1002/jpln.200700005

Eticha, D., Stass, A., and Horst, W. J. (2005). Cell-wall pectin and its degree of methylation in the maize root-apex: significance for genotypic differences in aluminium resistance. Plant Cell Environ. 28, 1410-1420. doi: 10.1111/j.13653040.2005.01375.x

Evans, C. D., Cullen, J. M., Alewell, C., Kopácek, J., Marchetto, A., Moldan, F., etal. (2001). Recovery from acidification in European surface waters. Hydrol. Earth Syst. Sci. 5, 283-297. doi: 10.5194/hess-5283-2001

FAO and IIASA. (2007). Mapping Biophysical Factors That Influence Agricultural Production and Rural Vulnerability. Rome: FAO and IIASA.

FAO/IIASA/ISRIC/ISS-CAS/JRC.

(2012). Harmonized World Soil Database, version 1.2. Rome: FAO/Laxenburg: IIASA.

Fowler, D., Cape, J. N., Coyle, M., Flechard, C., Kuylenstierna, J., Hicks, K., et al. (1999). The global exposure of forests to air pollution. Water
Air Soil Pollut. 116, 5-32. doi: 10.1023/A:1005249231882

Franceschi, V. R., and Nakata, P. A. (2005). Calcium oxalate in plants: formation and function. Annu. Rev. Plant Biol. 56, 41-71. doi: 10.1146/annurev.arplant.56.032604. 144106

Franco, C. R., Chagas, A. P., and Jorge, R. A. (2004). Ion-exchange equilibria with aluminum pectinates. $\mathrm{Col}$ loids Surf. A Physicochem. Eng. Asp. 204, 183-192. doi: 10.1016/S09277757(01)01134-7

Furukawa, J., Yamaji, N., Wang, H., Mitani, N., Murata, Y., Sato, K. et al. (2007). An aluminum-activated citrate transporter in barley. Plant Cell Physiol. 48, 1081-1091. doi: 10.1093/pcp/pcm091

Genenger, M., Zimmermann, S., Hallenbarter, D., Landolt, W., Frossard, E., and Brunner, I. (2003). Fine root growth and element concentrations of Norway spruce as affected by wood ash and liquid fertilisation. Plant Soil 255, 253-264. doi: 10.1023/A:1026118101339

Godbold, D. L., Fritz, H. W. Jentschke, G., Meesenburg, H., and Rademacher, P. (2003). Root turnover and root necromass accumulation of Norway spruce (Picea abies) are affected by soil acidity. Tree Physiol. 23, 915-921. doi: 10.1093/treephys/23.13.915

Gonzalez-Santana, I. H., MarquezGuzman, J., Cram-Heydrich, S., and Cruz-Ortega, R. (2012). Conostegia xalapensis (Melastomataceae): an aluminum accumulator plant. Physiol. Plant. 144, 134 145. doi: 10.1111/j.1399-3054.2011. 01527.x

Graf Pannatier, E., Thimonier, A., Schmitt, M., Walthert, L., and Waldner, P. (2011). A decade of monitoring at Swiss Long-Term Forest Ecosystem Research (LWF) sites: can we observe trends in atmospheric acid deposition and in soil solution acidity? Environ. Monit. Assess. 174, 3-30. doi: 10.1007/s10661-0101754-3

Grisel, N., Zoller, S., KünzliGontarczyk, M., Lampart, T., Münsterkotter, M., Brunner I., et al. (2010). Transcriptome responses to aluminum stress in roots of aspen (Populus tremula). BMC Plant Biol. 10:185. doi: 10.1186/1471-222910-185

Heim, A., Brunner, I., Frey, B., Frossard, E., and Luster, J. (2001). Root exudation, organic acids, and element distribution in roots of Norway spruce seedlings treated with aluminium in hydroponics. J. Plant Nutr. Soil Sci.
164, 519-526. doi: 10.1002/15222624(200110)164:5

Heim, A., Brunner, I., Frossard, E., and Luster, J. (2003). Aluminum effects on Picea abies at low solution concentrations. Soil Sci. Soc. Am. J. 67, 895-898. doi: 10.2136/sssaj2003. 0895

Heim, A., Luster, J., Brunner, I., Frey, B., and Frossard, E. (1999). Effects of aluminium treatment on Norway spruce roots: aluminium binding forms, element distribution, and release of organic acids. Plant Soil 216, 103-116. doi: 10.1023/A:1004728122261

Hirano, Y., Frey, B., and Brunner, I. (2012). Contrasting reactions of roots of two coniferous tree species to aluminum stress. Environ. Exp. Bot. 77, 2-18. doi: 10.1016/j.envexpbot.2011.10.007

Hirano, Y., Graf Pannatier, E., Zimmermann, S., and Brunner, I. (2004). Induction of callose in roots of Norway spruce seedlings after shortterm exposure to Al. Tree Physiol. 24, 1270-1283. doi: 10.1093/treephys/24.11.1279

Hirano, Y., Walthert, L., and Brunner, I. (2006). Callose in root apices of European chestnut seedlings; a physiological indicator of aluminium stress. Tree Physiol. 26, 431-440. doi: 10.1093/treephys/26.4.431

Hoekenga, O. A., Maron, L. G., Piñeros, M. A., Cançado, G. M., Shaff, J., Kobayashi, Y., et al. (2006). AtALMT1, which encodes a malate transporter, is identified as one of several genes critical for aluminum tolerance in Arabidopsis. Proc. Natl. Acad. Sci. U.S.A. 103, 9738-9743. doi: 10.1073/pnas.0602868103

Horst, W. J., Wang, Y., and Eticha, D. (2010). The role of the root apoplast in aluminium-induced inhibition of root elongation and in aluminium resistance of plants: a review. Ann. Bot. 106, 185-197. doi: 10.1093/aob/mcq053

Inostroza-Blancheteau, C., Rengel, Z., Alberdi, M., de la Luz Mora, M., Aquea, F., Arce-Johnson, P., et al. (2012). Molecular and physiological strategies to increase aluminum resistance in plants. Mol. Biol. Rep. 39, 2069-2079. doi: 10.1007/s11033011-0954-4

Ishikawa, S., Wagatsuma, T., Sasaki, R., and Ofei-Manu, P. (2000). Comparison of the amount of citric and malic acids in $\mathrm{Al}$ media of seven plant species and two cultivars each in five plant species. Soil Sci. Plant Nutr. 46, 751758. doi: 10.1080/00380768.2000.10 409141 
Jansen, S., Broadley, M. R., Robbrecht, E., and Smets, E. (2002). Aluminum hyperaccumulation in Angiosperms: a review of its phylogenetic significance. Bot. Rev. 68 , 235-269. doi: 10.1663/00068101(2002)068[0235:AHIAAR] 2.0.CO;2

Jansen, S., Watanabe, T., Dessein, S., Smets, E., and Robbrecht, E. (2003). A comparative study of metal levels in leaves of some Al-accumulating Rubiaceae. Ann. Bot. 91, 657-663. doi: 10.1093/aob/mcg071

Jones, D. L., and Ryan, P. R. (2003). "Aluminum toxicity," in Encyclopedia of Applied Plant Science, eds B. Thomas, D. Murphy, and B. G. Murray (London: Elsevier Academic Press), 656-664.

Kidd, P. S., and Proctor, J. (2000). Effects of aluminium on the growth and mineral composition of Betula pendula Roth. J. Exp. Bot. 51, 1057-1066. doi: 10.1093/jexbot/51.347.1057

Kinraide, T. B. (1997). Reconsidering the rhizotoxicity of hydroxyl, sulphate, and fluoride complexes of aluminium. J. Exp. Bot. 48, 1115-1124. doi: $10.1093 / j x b / 48.5 .1115$

Kinraide, T. B. (2003). Toxicity factors in acidic forest soils: attempts to evaluate separately the toxic effects of excessive $\mathrm{Al}^{3+}$ and $\mathrm{H}^{+}$and insufficient $\mathrm{Ca}^{2+}$ and $\mathrm{Mg}^{2+}$ upon root elongation. Eur. J. Soil Sci. 54, 323-333. doi: 10.1046/j.13652389.2003.00538.x

Kochian, L. V. (1995). Cellular mechanisms of aluminum toxicity and resistance in plants. Annu. Rev. Plant Physiol. Plant. Mol. Biol. 46, 237-260. doi: 10.1146/annurev.pp.46.060195.001321

Kochian, L. V., Hoekenga, O. A., and Pineros, M. A. (2004). How do crop plants tolerate acid soils? mechanisms of aluminum tolerance and phosphorous efficiency. Annu. Rev. Plant Biol. 55, 459-493. doi: 10.1146/annurev.arplant.55.031903. 141655

Kochian, L. V., Pineros, M. A., and Hoekenga, O. A. (2005). The physiology, genetics and molecular biology of plant aluminum resistance and toxicity. Plant Soil 274, 175-195. doi: 10.1007/s11104-004-1158-7

Larsen, P. B., Cancel, J., Rounds, M., and Ochoa, V. (2007). Arabidopsis ALS1 encodes a root tip and stele localized half type $\mathrm{ABC}$ transporter required for root growth in an aluminum toxic environment. Planta 225, 1447-1458. doi: 10.1007/s00425-006-0452-4

Larsen, P. B., Degenhardt, J., Tai, C. Y., Stenzler, L. M., Howell, S. H., and Kochian, L. V. (1998).
Aluminum-resistant Arabidopsis mutants that exhibit altered patterns of aluminum accumulation and organic acid release from roots. Plant Physiol. 117, 9-18. doi: 10.1104/pp.117.1.9

Larsen, P. B., Geisler, M. J. B., Jones, C. A., Williams, K. M., and Cancel, J. D. (2005). ALS3 encodes a phloemlocalized $\mathrm{ABC}$ transporter-like protein that is required for aluminum tolerance in Arabidopsis. Plant J. 41, 353-363. doi: 10.1111/j.1365313X.2004.02306.x

Larsen, P. B., Kochian, L. V., and Howell, S. H. (1997). Al inhibits both shoot development and root growth in als3, an Al-sensitive Arabidopsis mutant. Plant Physiol. 114, 1207-1214.

Larssen, T., Lydersen, E., Tang, D., He, Y., Gao, J., Liu, H., et al. (2006). Acid rain in China. Environ. Sci. Technol. 40, 418-425. doi: 10.1021/es0626133

Leuschner, C., Hertel, D., Schmid, I. Koch, O., Muhs, A., and Hölscher, D. (2004). Stand fine root biomass and fine root morphology in oldgrowth beech forests as a function of precipitation and soil fertility. Plant Soil 258, 43-56. doi: 10.1023/ B:PLSO.0000016508.20173.80

Li, L., Tutone, A. F., Drummond, R. S. M., Gardner, R. C., and Luan, S. (2001). A novel family of magnesium transport genes in Arabidopsis. Plant Cell 13, 2761-2775.

Libert, B., and Franceschi, V. R. (1987). Oxalate in crop plants. J. Agric. Food Chem. 35, 926-938. doi: 10.1021/jf00078a019

Ligaba, A., Katsuhura, M., Ryan P. R., Shibasaka, M., and Matsumoto, H. (2006). The BnALMT1 and BnALMT2 genes from rape encode aluminum-activated malate transporters that enhance the aluminum resistance of plant cells. Plant Physiol. 142, 1294-1303. doi: 10.1104/pp.106.085233

Ma, J. F. (2007). Syndrome of aluminum toxicity and diversity of aluminum resistance in higher plants. Int. Rev. Cytol. 264, 225-252. doi: 10.1016/S0074-7696(07)64005-4

Ma, J. F., Ryan, P. R., and Delhaize, E. (2001). Aluminum tolerance in plants and the complexing role of organic acids. Trends Plant Sci. 6, 273-278. doi: 10.1016/S13601385(01)01961-6

Magalhaes, J. V., Liu, J., Guimarães, C. T., Lana, U. G. P., Alves, V. M. C., Wang, Y. H., et al. (2007). A gene in the multidrug and toxic compound extrusion (MATE) family confers aluminum tolerance in sorghum. Nat. Genet. 39, 1156-1161. doi: $10.1038 / \mathrm{ng} 2074$
Maron, L. G., Kirst, M., Mao, C., Milner, M. J., Menossi, M., and Kochian, L. V. (2008). Transcriptional profiling of aluminum toxicity and tolerance responses in maize roots. New Phytol. 179, 116-128. doi: 10.1111/j.14698137.2008.02440.x

Martin, F., Rubini, P., Cote, R., and Kottke, I. (1994). Aluminum polyphosphate complexes in the mycorrhizal basidiomycete Laccaria bicolor: a ${ }^{27} \mathrm{Al}$-nuclear magnetic resonance study. Planta 194, 241-246. doi: 10.1007/BF011 01683

Masunaga, T., Kubota, D., Hotta, M., and Wakatsuki, T. (1998). Mineral composition of leaves and bark in aluminium accumulators in a tropical rain forest in Indonesia. Soil Sci. Plant Nutr. 44, 347-358. doi: 10.1080/00380768.1998.10414456

Matsumoto, H., Hirasawa, E. Morimura, S., and Takahashi, E. (1976). Localization of aluminium in tea leaves. Plant Cell Physiol. 17, 627-631. doi: 10.1007/s10265-010-0344-3

Matsumoto, H., and Motoda, H. (2012). Aluminum toxicity recovery processes in root apices. Possible association with oxidative stress Plant Sci. 185-186, 1-8. doi: 10.1016/j.plantsci.2011.07.019

Matsumoto, H., and Motoda, H. (2013). Oxidative stress is associated with aluminum toxicity recovery in apex of pea root. Plant Soil. 363, 399-410. doi: 10.1007/s11104-012-1396-Z.

Mazen, A. M. A. (2004). Calcium oxalate deposits in leaves of Corchorus olitorius as related to accumulation of toxic metals. Russ. J. Plant Physiol. 51, 281-285. doi: 10.1023/ B:RUPP.0000019226.03536.21

Metali, F., Salim, K. A., and Burslem, D. F. R. P. (2012). Evidence of foliar aluminium accumulation in local, regional and global datasets of wild plants. New Phytol. 193, 637-649. doi: 10.1111/j.14698137.2011.03965.x

Mohnen, D. (2008). Pectin structure and biosynthesis. Curr. Opin. Plant Biol. 11, 266-277. doi: 10.1016/j.pbi.2008.03.006

Morita, A., Horie, H., Fujii, Y., Takatsu, S., Watanabe, H., Yagi, A., etal. (2004). Chemical forms of aluminum in xylem sap of tea plants (Camellia sinensis L.). Phytochemistry 65, 2775-2780. doi: 10.1016/j.phytochem.2004.08.043

Morita, A., Yanagisawa, O., Maeda, S., and Hiradate, S. (2008). Mechanism for the detoxification of aluminum in roots of tea plant (Camellia sinensis (L.) Kuntze).
Phytochemistry 69, 147-153. doi: 10.1016/j.phytochem.2007.06.007

Morita, A., Yanagisawa, O., Maeda, S., Takatsu, S., and Ikka, T. (2011). Tea plant (Camellia sinensis L.) roots secrete oxalic acid and caffeine into medium containing aluminium. Soil Sci. Plant Nutr. 57, 796-802. doi: 10.1080/00380768.2011.629176

Nagata, T., Hayatsu, M., and Kosuge, N. (1992). Identification of aluminium forms in tea leaves by ${ }^{27} \mathrm{Al} \mathrm{NMR}$. Phytochemistry 31, 1215-1218. doi: 10.1016/0031-9422(92)80263-E

Naik, D., Smith, E., and Cumming, J. R. (2009). Rhizosphere carbon deposition, oxidative stress and nutritional changes in two poplar species exposed to aluminum. Tree Physiol. 29, 423-436. doi: 10.1093/treephys/tpn035

Nguyen, N. T., Nakabayashi, K., Thompson, J., and Fujita, K. (2003). Role of exudation of organic acids and phosphate in aluminum tolerance of four tropical woody species. Tree Physiol. 23, 1041-1050. doi: 10.1093/treephys/23.15.1041

Ofei-Manu, P., Wagatsuma, T., Ishikawa, S., and Twaraya, K. (2001). The plasma membrane strength of the root-tip cells and root phenoliccompounds are correlated with $\mathrm{Al}$ tolerance in several common woody plants. Soil Sci. Plant Nutr. 47, 359375. doi: 10.1080/00380768.2001.104 08399

Olivares, E., Colonnello, G., Pena, E., and Rodriguez, L. (2010). Aluminum accumulation in nineteen Melastomataceae species from three contrasting plant formations in acid soils. $J$. Plant. Nutr. Soil Sci. 183, 453-460. doi: 10.1002/jpln.200900152

Osaki, M., Watanabe, T., and Tadano, T. (1997). Beneficial effect of aluminum on growth of plants adapted to low $\mathrm{pH}$ soils. Soil Sci. Plant Nutr. 43, 551-563. doi: 10.1080/00380768.1997.10414782

Osawa, H., Endo, I., Hara, Y., Matsushima, Y., and Tange, T. (2011). Transient proliferation of proanthocyanidin-accumulating cells on the epidermal apex contributes to highly aluminum-resistant root elongation in camphor tree. Plant Physiol. 155, 433-446. doi: 10.1104/ pp. 110.166967

Osawa, H., Ikeda, S., and Tange, T. (2013). The rapid accumulation of aluminum is ubiquitous in both the evergreen and deciduous leaves of Theaceae and Ternstroemiaceae plant over a wide $\mathrm{pH}$ range in acidic soils. Plant Soil 363, 49-59. doi: 10.1007/s11104-0121285-5 
Poschenrieder, C., Gunsé, B., Corrales, I., and Barceló, J. (2008). A glance into aluminum toxicity and resistance in plants. Sci. Total Environ. 400, 356-368. doi: 10.1016/j.scitotenv.2008.06.003

Qin, R., Hirano, Y., and Brunner, I. (2007). Exudation of organic acid anions from poplar roots after exposure to $\mathrm{Al}, \mathrm{Cu}$ and $\mathrm{Zn}$. Tree Physiol. 27, 313-320. doi: 10.1093/treephys/27.2.313

Rahman, M. M., and Kawamura, O (2011). Oxalate accumulation in forage plants: some agronomic, climatic and genetic aspects. Asian-australas. J. Anim. Sci. 24, 439-448. doi: 10.5713/ajas.2011.10208

Rangel, A. F., Rao, I. M., and Horst, W. J. (2009). Intracellular distribution and binding state of aluminium in root apices of two common bean (Phaseolus vulgaris) genotypes in relation to Al toxicity. Physiol. Plant. 135, 162-173. doi: 10.1111/j.13993054.2008.01183.x

Richter, A. K., Hajdas, I., Frossard, E., and Brunner, I. (2013). Soil acidity affects fine root turnover of European beech. Plant Biosyst. 147, 50-59. doi: 10.1080/11263504.2012.742471

Richter, A. K., Hirano, Y., Luster, J., Frossard, E., and Brunner, I. (2011). Soil base saturation affects root growth of European beech seedlings. J. Plant Nutr. Soil Sci. 174, 408-419. doi: 10.1002/jpln.200900351

Richter, A. K., Walthert, L., Frossard, E., and Brunner, I. (2007). Does low soil base saturation affect the vitality of fine roots of European beech? Plant Soil 298, 69-79. doi: 10.1007/s11104007-9338-x

Ryan, P. R., and Delhaize, E. (2010). The convergent evolution of aluminium resistance in plants exploits a convenient currency. Funct. Plant Biol. 37, 275-284. doi: 10.1071/FP09261

Ryan, P. R., DiTomaso, J. M., and Kochian, L. V. (1993). Aluminium toxicity in roots: an investigation of spatial sensitivity and the role of the root cap. J. Exp. Bot. 44, 437-446. doi: 10.1093/jxb/44.2.437

Ryan, P. R., Tyerman, S. D., Sasaki, T., Furuichi, T., Yamamoto, Y., Zhang, W. H., et al. (2011). The identification of aluminium-resistance genes provides opportunities for enhancing crop production on acid soils. J. Exp. Bot. 62, 9-20. doi: 10.1093/jxb/erq272

Sasaki, T., Yamamoto, Y., Ezaki, B., Katsuhara, M., Ahn, S. J., Ryan, P. R., et al. (2004). A wheat gene encoding an aluminum-activated malate transporter. Plant J. 37, 645-653. doi: 10.1111/j.1365-313X.2003.01991.x
Schachtschabel, P., Blume, H. P., Brümmer, G., Hartge, K. H., and Schwertmann, U. (1992). Lehrbuch der Bodenkunde, 13 Auflage. Stuttgart: Ferdinand Enke Verlag.

Schreeg, L. A., Kress, W. J., Erickson, D. L., and Swenson, N. G. (2010). Phylogenetic analysis of local-scale tree soil associations in a lowland moist tropical forest. PLoS ONE 5:e13685. doi 10.1371/journal.pone.0013685

Silva, I. R., Novais, R. F., Jham, G. N., Barros, N. F., Gebrim, F. O., Nunes, F. N., et al. (2004). Responses of eucalypt species to aluminum: the possible involvement of low molecular weight organic acids in the $\mathrm{Al}$ tolerance mechanism. Tree Physiol. 24, 1267-1277. doi: 10.1093/treephys/24.11.1267

Smith, E., Naik, D., and Cumming, J. R. (2011). Genotypic variation in aluminum resistance, cellular aluminum fractions, callose and pectin formation and organic acid accumulation in roots of Populus hybrids. Environ. Exp. Bot. 72, 182-193. doi: 10.1016/j.envexpbot.2011.03.003

Smits, M. M., and Hoffland, E. (2009). Possible role of ectomycorrhizal fungi in cycling of aluminium in podzols. Soil Biol. Biochem. 41, 491-497. doi: 10.1016/j.soilbio.2008.11.023

Stoddard, J. L., Jeffries, D. S., Lükeville, A., Clair, T. A., Dillon, P. J., Driscoll, C. T., et al. (1999). Regional trends in aquatic recovery from acidification in North America and Europe. Nature 401, 575-578. doi: 10.1038/44114

Sverdrup, H., and Warfvinge, P. (1993). The Effect of Soil Acidification on the Growth of Trees, Grass, and Herbs as Expressed by the $(\mathrm{Ca}+\mathrm{Mg}+\mathrm{K}) / \mathrm{Al}$ Ratio, Vol. 2, Report in Ecology and Environmental Engineering. Lund: Lund University.

Tabuchi, A., and Matsumoto, H. (2001). Changes in cell-wall properties of wheat (Triticum aestivum) roots during aluminuminduced growth inhibition. Physiol. Plant. 112, 353-358. doi: 10.1034/j.1399-3054.2001.1120308.x

Tahara, K., Norisada, M., Tange, T., Yagi, H., and Kojima, K. (2005). Ectomycorrhizal association enhances $\mathrm{Al}$ tolerance by inducing citrate secretion in Pinus densiflora. Soil Sci. Plant Nutr. 51, 397-403. doi: 10.1111/j.1747-0765.2005.tb00045.x

Tahara, K., Norisada, M., Yamanoshita, T., and Kojima, K. (2008). Role of binding ligands in aluminum resistance of Eucalyptus camaldulensis and Melaleuca cajuputi. Plant Soil 302 175-187. doi: 10.1007/s11104-0079464-5
Thompson, K., Parkinson, J. A., Band, S. R., and Spencer, R. E. (1997). A comparative study of leaf nutrient concentrations in a regional herbaceous flora. New Phytol. 136, 679-689. doi 10.1046/j.1469-8137.1997.00787.x

Tolra, R., Vogel-Mikus, K., Hajiboland, R., Kump, P., Pongrac, P., Kaulich, B., et al. (2011). Localization of aluminium in tea (Camellia sinensis) leaves using low energy $\mathrm{X}$ ray fluorescence spectro-microscopy. J. Plant Res. 124, 165-172. doi: 10.1007/s10265-010-0344-3

Ulrich, B., Mayer, R., and Khanna, P. K. (1980). Chemical changes due to acid precipitation in a Loess-derived soil in Central Europe. Soil Sci. 130, 193-199. doi: 10.1097/00010694198010000-00005

Vanguelova, E., Hirano, Y., Eldhuset, T. D., Sas-Paszt, L., Bakker, M. R., Püttsepp, U., etal. (2007) Tree fine root $\mathrm{Ca} / \mathrm{Al}$ molar ratio indicator of $\mathrm{Al}$ and acidity stress. Plant Biosyst. 141, 460-480. doi: 10.1080/11263500701626192

von Uexküll, H. R., and Mutert, E. (1995). Global extent, development and economic impact of acid soils. Plant Soil 171, 1-15. doi: 10.1007/BF00009558

Walthert, L., Graf Pannatier, E., and Meier, E. S. (2013). Shortage of nutrients and excess of toxic elements in soils limit the distribution of soil-sensitive tree species in temperate forests. For. Ecol. Manag. 297, 94-107. doi: 10.1016 j.foreco.2013.02.008

Watanabe, T., and Osaki, M. (2001) Influence of aluminum and phosphorus on growth and xylem sap composition in Melastoma mala bathricum L. Plant Soil 237, 63-70. doi: 10.1023/A:1013395814958

Watanabe, T., Osaki, M., and Tadano, T. (1997). Aluminum-induced growth stimulation in relation to calcium, magnesium and silicate nutrition in Melastoma malabathricum L. Soil Sci. Plant Nutr. 44, 655-666. doi 10.1080/00380768.1998.10414489

Weber-Blaschke, G., Claus, M., and Rehfuess, K. E. (2002). Growth and nutrition of ash (Fraxinus excelsior L.) and sycamore (Acer pseudoplatanus L.) on soils of different base saturation in pot experiments. For. Ecol. Manag. 167, 43-56. doi: 10.1016/S0378-1127(01) 00698-3

Westman, W. E. (1975). Edaphic climax pattern of the pygmy forest region of California. Ecol. Monogr. 45, 109-135. doi: 10.2307/ 1942403
Wilkins, D. A., and Hodson, M. J. (1989). The effects of aluminium and Paxillus involutus Fr. on the growth of Norway spruce [Picea abies (L.) Karst.]. New Phytol. 113, 225-232. doi: 10.1111/j.14698137.1989.tb04709.x

Yang, J. L., Li, Y. Y., Zhang, Y. J., Zhang, S. S., Wu, Y. R., Wu, P., etal. (2008). Cell wall polysaccharides are specifically involved in the exclusion of aluminum from the rice root apex. Plant Physiol. 146, 602-611. doi: 10.1104/pp.107. 111989

Yang, L. T., Jiang, H. X., Tang, N., and Chen, L. S. (2011). Mechanisms of aluminum-tolerance in two species of citrus: secretion of organic acid anions and immobilization of aluminum by phosphorus in roots. Plant Sci. 189, 521530. doi: 10.1016/j.plantsci.2010. 11.011

Zang, U., Lamersdorf, N., and Borken, W. (2011). Response of the fine root system in a Norway spruce stand to 13 years of reduced atmospheric nitrogen and acidity input. Plant Soil 339, 435-445. doi: 10.1007/s11104-0100598-5

Zysset, M., Brunner, I., Frey, B., and Blaser, P. (1996). Response of European chestnut to varying calcium/aluminum ratios. $J$. Environ. Qual. 25, 702-708. doi: $10.2134 /$ jeq1996.0047242500250004 0009x

Conflict of Interest Statement: The authors declare that the research was conducted in the absence of any commercial or financial relationships that could be construed as a potential conflict of interest.

Received: 01 March 2013; accepted: 14 May 2013; published online: 12 June 2013.

Citation: Brunner I and Sperisen C (2013) Aluminum exclusion and aluminum tolerance in woody plants. Front. Plant Sci. 4:172. doi: 10.3389/ fpls.2013.00172

This article was submitted to Frontiers in Functional Plant Ecology, a specialty of Frontiers in Plant Science.

Copyright $\odot 2013$ Brunner and Sperisen. This is an open-access article distributed under the terms of the Creative Commons Attribution License, which permits use, distribution and reproduction in other forums, provided the original authors and source are credited and subject to any copyright notices concerning any thirdparty graphics etc. 